\title{
THE WESTERN BALKANS' ENERGY SECURITY IN A TRIANGLE: THE ROLE OF THE EU, RUSSIA AND TURKEY ${ }^{3}$
}

https://doi.org/10.18485/iipe_balkans_rssc.2020.ch8

\begin{abstract}
One of the key dimensions of vivid security dynamics in the Western Balkans is concerned with its energy security, especially when considering its specific geographical position within crossed energy transportation routes between East and West. The international pipeline connection of diverse states into one regional cluster made the theme of energy security in terms of natural gas very important. The main research question is: What makes the state-of-the-art in the Western Balkans' energy security within the context of growing Turkey's role, besides the EU and Russia? Consequently, the main hypothesis refers to the increasing role of Turkey in the Western Balkans' energy security. Reorienting of the EU and Russia to the supplying of South Europe via southern pipelines resulted in the increased role of Turkey in terms of the new 'energy hub'. The energy security dynamics of the Western Balkans will be examined through case studies regarding the Southern Gas Corridor and the Turk Stream, which are making Turkey a significant actor on the EastWest energy supply route. According to the already mentioned regional nature of pipelines, the analysis will shed light on the Regional Security Complex Theory (RSCT) and its main concepts, such as geographical proximity of these actors and their historical and cultural relations. In accordance, the role of Turkey as an insulator state in terms of RSCT will be revised. The analysis employed a literature review and qualitative content analysis of key political and security statements and media releases as well, made in regard to energy actors identified. Although the quantitative data sources were consulted, the research is of a predominantly qualitative nature.
\end{abstract}

Keywords: the Western Balkans, energy security, the EU, Russia, Turkey, pipelines, natural gas.

\footnotetext{
${ }^{1}$ Research Assistant, Institute of International Politics and Economics, Belgrade. E-mail: nevena.sekaric@diplomacy.bg.ac.rs.

${ }^{2}$ Research Assistant, Institute of International Politics and Economics, Belgrade. E-mail: vuk.lazic@diplomacy.bg.ac.rs.

${ }^{3}$ The paper presents findings of a study developed as a part of the research project "Serbia and challenges in international relations in 2020", financed by the Ministry of Education, Science, and Technological Development of the Republic of Serbia, and conducted by Institute of International Politics and Economics, Belgrade.
} 


\section{INTRODUCTION}

Labeling energy as a key contemporary challenge makes this resource one of the most important in terms of international relations. The fact that normal functioning and development of all societies depend on the availability and accessibility of energy resources makes the theme of energy security justifiable in terms of scientific researches (Trapara and Šekarić, 2019). While some energy resources, such as oil, are determined through the existence of the global market, natural gas issues are a little bit of different nature. The natural gas issue refers to a strong regional dimension due to several kilometers long international pipelines that link diverse states into one regional cluster. This formation, which gathers different states in terms of producers, transit states and consumers, is characterized by specific regional security dynamics and diverse, often divergent energy interest of energy actors. With the global energy shift to the concept of diversifying energy routes and resources, rerouting energy trajectories creates new forms of energy dependence and cooperation, while some new actors become significant in the context of energy relations. One of the best examples of the mentioned refers to Turkey as 'emerging as an indispensable partner to Europe' (Yorucu and Mehmet, 2018, p. 1).

Turkey is not an energy producer but sits near more than three-quarters of the global proven hydrocarbon reserves and, therefore, presents an important energy transit country. In addition, its geographic position in terms of newest diversification projects of both the EU and Russia makes it a significant state in the context of the Western Balkans' energy security. This specifically refers to the Southern Gas Corridor (EU gas project) and the Turk Stream Natural Gas Pipeline Project (Turk Stream (Russian gas project)) due to their transportation lines that go through or near to the WB states.

The Western Balkans (WB) represents the region that sits historically between East and West. Moreover, this region is often presented as one of the 'battlegrounds of the energy game unfolding between Russia and the EU' (Önsoy and Udum, 2015, p. 176). The Western Balkans countries, however, have not been able so far to capitalize on this key location and draw benefits as transit countries (Ralchev, 2012, p. 1). Therefore, the main goal of this paper is to gain insight into the state-of-the-art of the Western Balkans' energy security dynamics within the context of growing Turkey's role, besides the EU and Russia. 


\section{THE REGIONAL SECURITY COMPLEX THEORY AND THE CASE OF TURKEY}

The regional security complex theory (RSCT) was originally developed by the theorists of the Copenhagen School of Security Studies. It rests on the premise that 'no nation's security is self-contained' according to an inherently relational nature of security dynamics (Buzan and Wæver, 2003, p. 43). In other words, 'The region refers to the level where states or other units link together sufficiently closely that their securities cannot be considered separate from each other' (Buzan and Wæver, 2003, p. 43), where the geographical proximity of the states or units concerned is the most prominent.

According to the main presumptions of RSCT, Turkey is seen as an insulator between the Middle Eastern RSC, European and the post-Soviet RSC, playing a peripheral role in the international system, thus making it unable to identify as part of any particular region. ${ }^{4}$ The role of an insulator state Turkey has gained due to its inability 'to bring different regional security complexes together to form its own strategic arena or to clearly present itself as a pole in any regional security complex' (Luenam, 2015, p. 4). In other words, sitting on the edge of three regional security complexes makes Turkey, although a very important geopolitical actor, unable to be more present and involved in the security dynamics of its neighbors. However, in terms of changing Turkey's previous foreign and security policy in the 21st century, intensification of its relations with its neighbors (Barrinha, 2014, p. 166) and recent energy security dynamics, this position must be questioned because it reaches beyond its own traditional peripheral and passive role characteristic of an insulator states.

Turkey's geographical position between diverse regional complexes gives it the potential for greater involvement in regional security dynamics. When it comes to the Western Balkans countries, Turkey is seen as a traditional actor having historical and cultural interests within this area (Buzan and Wæver, 2003, p. 395). With recent diplomatic visits of the Turkish president to the Balkans countries, Turkey's interests in developing

\footnotetext{
${ }^{4}$ The concept of an insulator is specific to RSCT and implies 'a location occupied by one or more units where larger regional security dynamics stand back to back. This is not to be confused with the traditional idea of a buffer state, whose function is defined by standing at the center of a strong pattern of securitization, not at its edge' (Buzan and Wæver, 2003, p. 41). Insulators are not located in the regional security complex but rather sit in-between two or more regional security complexes (Buzan and Wæver, 2003, p. 483).
} 
and implementing business projects and, especially, energy presence in this part of Europe, make Turkey very present and active in the Western Balkans. On the other side, growing Turkish-Russian relations primarily in energy security issues, make this state close to Russia a great power of the postSoviet regional security complex. However, Turkey sees itself as a 'bridge between gas-producing and gas-consuming countries' (GIS Dossier, 2018). Therefore, the statement of Buzan and Wæver that Turkey, as insulator state, is unable 'to bring the different complexes together into one coherent strategic arena' (2003, p. 395), becomes questionable when having on mind recent events linked to energy security, especially Turkey's ambitions to become a regional energy hub. Rather, as Barrinha suggested (2014), Turkey could become a great power insulator, not necessarily passing the process from being a regional and great power successively.

\section{ENERGY MIX OF THE WESTERN BALKANS COUNTRIES}

The Western Balkans, although geographically set, consists of countries that have not been integrated into the EU by the treaties from 2004 and 2007. Hence, the Western Balkans includes 'former Yugoslavia countries minus Slovenia plus Albania'. ${ }^{5}$ This 'formula' actually stands for political and discursive designation of this region rather than its geographical determination. Some studies are showing the justification of thematizing the Western Balkans as a peculiar regional security subcomplex (as a part of European regional security complex) (Lipovac, 2016; Kudlenko, 2018; Veličkovski Stojanovski, 2019).

The diverse energy mix of the WB region is the result of the different energy needs of the Western Balkans countries. However, the mutual reliance of these countries on each other and mutual energy connections consequently lead to a spillover effect in the domain of energy security. Setting aside the consumption of petroleum and lignite as still dominant resources, the Western Balkans countries are highly dependent on Russian oil and gas. According to some data, Serbia and Croatia import the most natural gas from all Western Balkans countries (UN, 2016; Gazprom Export,

\footnotetext{
${ }^{5}$ The Western Balkans was formally set in 2003 during the EU-Western Balkans Summit in Thessaloniki that gathered six WB countries and confirmed their pathway towards the EU membership (European Council, 2003). Besides, Croatia is considered as part of the WB region regardless of its EU membership because of its strong historical, political and security bondages with the rest of the Western Balkans countries.
} 
2019), where Serbia is the most dependent country from Russian natural gas. Russian gas supplies the Western Balkans countries via a pipeline that passes through Hungary and Serbia or Bulgaria. Considering that Russian energy resources (primarily oil and natural gas) dominate the Western Balkans import portfolio, the role of Russia is obviously the most important. ${ }^{6}$ However, dependence on a single supplier is marked as a threat to the energy security of the consuming country, making space for countries' attempts to diversify supplying routes. ${ }^{7}$

The Western Balkans states face diverse problems when it comes to their energy security. Problems such as frazzle and ruined energy infrastructure, high $\mathrm{CO}_{2}$ emissions and many others, make the need for its recovery urgent (Lachert and Kamiński, 2019). ${ }^{8}$ A huge amount of energy infrastructure of those countries was damaged in the civil war during the ' 90 s, while the rest of it desperately needs reconstruction. Pipelines that pass through or nearby these countries are seen as an opportunity to enrich their own energy security. Strong regional cooperation in the domain of energy security has never been more at stake than now, especially between non-EU members and the rest of the European Union.

Although the South Stream project (Russian gas project) was a desirable pipeline for most of the Western Balkans because of its direct transportation via these countries ${ }^{9}$, it has never been finished. Therefore, the Russian gas project Turk Stream is now seen as the successor of a previously failed project and one of the burning issues when it comes to enhancing the energy security of the Western Balkans region.

\footnotetext{
${ }^{6}$ Russian Gazprom is the main gas supplier to the entire region and the only producer of domestic gas (and oil) in Serbia (Kovacevic, 2017, p. v).

${ }^{7}$ As a great example of this situation could serve the event from the winter in 2009 when Russia cut the gas supply to Ukraine. Consequently, Croatia and Serbia received 'only 10 $\%$ of the normal amount for a week; following that, all gas supplies to the Western Balkans was cut off' (Önsoy and Udum, 2015, p. 182).

${ }^{8}$ In these terms, the region is still using old energy infrastructure built based on the Soviet bloc technology during the second half of the 20th century (Trapara and Šekarić, 2019).

${ }^{9}$ For instance, Gazprom and Srbijagas have constructed the world's largest gas storage facility at Banatski Dvor in the Republic of Serbia; North Macedonia signed a bilateral agreement with Russia in June 2013 aimed at the construction of a South Stream gas line for supplying this country. The same month, Serbia and Gazprom signed a roadmap to implement energy projects in the Republic of Srpska in regard to the South Stream project (Önsoy and Udum, 2015, p. 181).
} 


\section{ENERGY ROLES OF THE EU AND RUSSIA IN THE WESTERN BALKANS}

Although the Western Balkans was not the primary interest of the EU or Russia in terms of initial energy relations compared to some other European countries and routs, its role has been increased recently, especially when it comes to the Southern Gas Corridor (EU natural gas project) and the Turk Stream (Russian natural gas project).

Regarding the EU's energy policy towards the Balkans (and the rest of Southern and Eastern Europe), it is important to note that these countries are part of the European Energy Community established in 2006 to create harmonization of national legislation with the EU acquis communautaire in the domain of energy and integrate the European energy market. This kind of integration is often seen as the 'EU attempts to incorporate regional states into its own overall energy network', thus trying to decrease its energy dependence from Russia (Önsoy and Udum, 2015, p. 176). So far, the EU has been the major investor when it comes to the Western Balkans energy sectors whose main instruments in this context are the IPA funds and the WBIF initiative (Nedučin, 2018, p. 21).$^{10}$ The significance of the Western Balkans region in terms of the EU energy demands relies on the fact that the Western Balkans 'hosts three overlapping EU energy corridors: Central/South Eastern Electricity Connection, North-South Gas Interconnections \& Oil Supply and Southern Gas Corridor' (Kovacevic, 2017, p. 1). Lately, in the context of the EU energy policy, the Western Balkans is seen as a key part of the EU's attempts to diversify gas supplies. The EU's energy interest towards this region raises local expectations of transit rents and cheaper gas prices,

\footnotetext{
${ }^{10}$ In the context of investing in energy sectors in the Western Balkans, China has lately become one of the main investors as those countries are part of the 17+1 Initiative. For more detailed information, see: Zakić and Radišić, 2019.

${ }^{11}$ Currently, the Southern Gas Corridor is comprised of two parts: the Trans-Anatolian Pipeline (TANAP) (beginning at the Georgian-Turkish border, connecting to the existing Baku-Tbilisi-Erzurum pipeline (BTE), and transporting Azerbaijani gas from the Caspian Sea gas field of Shah Deniz II), and the Trans-Adriatic Pipeline (TAP). At the Turkish-Greek border, gas from the TANAP flows into the TAP, which leads from Thessaloniki through Albania and the Adriatic Sea to Italy and further into Europe with a capacity of approximately $10 \mathrm{bcm} / \mathrm{y}$ of gas. It is often mentioned that 'gas from the TAP could be transported into Southeastern Europe along the coast of the Adriatic Sea by the IonianAdriatic Pipeline (IAP), which will pump up to $5 \mathrm{bcm} / \mathrm{y}$ of gas through Albania, Montenegro, Macedonia, and Croatia' (Tichy, 2019, p. 35).
} 
especially in the context of the Southern Gas Corridor ${ }^{11}$ and the North-South Gas Corridor ${ }^{12}$.

When it comes to Russia, it is worth of the notion that, in addition to Western Europe, Central and Eastern Europe represent a very important energy market for this country. With exports reaching $38.38 \mathrm{bcm}$ in 2018, according to the latest data, Russian gas provides more than half of the region's gas consumption (Gazprom Export, 2019, p. 7). A significant part of these exports goes to meet the needs of Bulgaria in the amount of $3.17 \mathrm{bcm}$, for Romania $1.32 \mathrm{bcm}$, but also for the Western Balkans, where Serbia receives $2.15 \mathrm{bcm}$ as the largest importer of Russian natural gas and Croatia with $2.04 \mathrm{bcm}$. Significantly smaller quantities go to Bosnia and Herzegovina in the amount of $0.24 \mathrm{bcm}$ and Macedonia in the amount of $0.16 \mathrm{bcm}$ in 2018. Due to the enormous dependence on Russian gas, which accounts for over $95 \%$ of total imports of this energy product in the Western Balkans, Russia is the most important and dominant energy player (Index Mundi, 2019). ${ }^{13}$ Besides, the Balkans is seen as a traditional Russian zone of interest, where the multi-polar distribution of power is the only tenable solution. Bearing in mind that a significant part of both Russian national security and foreign policy activities relies on its energy sources, it is expected that Russia will endeavor to maintain its role as a dominant provider of gas and oil to both the EU and the Western Balkans region. Besides, a Russian decision to stop gas supply to Europe via the Ukrainian transit route highlighted the importance of the southern part of the European continent with its potential of supplying route. In this power constellation, the importance of the Western Balkans in terms of energy security is growing.

\section{TURKEY'S ROLE IN THE WESTERN BALKANS}

\section{Historical and cultural bondages between Turkey and the Western Balkans}

Traditionally Turkey's role is well-known in the Western Balkans while the new one in terms of energy security starts to appear. Turkish foreign

\footnotetext{
12 The North-South Gas Corridor connects the LNG Terminal in Świnoujście with the Baltic Pipe, passing central Poland, the Czech Republic, Slovakia, Hungary, and the LNG terminal in Croatia eventually.

${ }^{13}$ Although there are no official and unique data on the dependence of the Western Balkans countries on Russian gas, this conclusion is reached through the crossing of official Gazprom data on natural gas exports and CIA Factbook data on the total consumption of this energy product classified by the same countries.
} 
policy towards the Balkans is conditioned by historical, political, economic, cultural and security determinants. In addition to legitimizing itself as the civilizing heir to the Ottoman Empire, Turkey's Balkans policy is based on the aspiration for restoration of the Ottoman cultural and political heritage, a paternalistic attitude towards the Balkans Muslims (Albanians and Bosniaks), and a tendency to rise in regional power with intense economic, trade and energy relations with the Balkans countries. A shift in foreign policy activities of Turkey is also seen within the amity-enmity pattern or, as Barinha stated, 'Turkey has also moved from a security perception based on enmity relations with its neighbors to one, if not of amity, at least of stronger convergence of interests' (2014, p. 178-179). Following a series of political failures and an erosion of its mediating capacities, Turkey is gaining more importance and attention in developing economic, trade and energy relations with the Balkans countries.

The ambitious and also unrealized Nabucco pipeline project raised for the first time the issue of Turkey's energy role in the Balkans. However, the actualization of its energy role was marked by the projects of the TransAtlantic Pipeline and the Turk Stream, which, according to the capacities and construction dynamics, represent a considerably realistic option.

\section{Turkey's role in the Western Balkans' energy security}

Since the Ataturk's period, the issue of energy independence, as a factor of economic development and overall power, has been on the top of Turkey's national-state agenda, from which an energy standpoint poses an ambivalent potential. While the absence of key energy sources (oil and natural gas) and high levels of demand make Turkey an energy-dependent, the extremely favorable geostrategic and geo-economic position between Russia, the Caucasus, Central Asia and the Middle East (which accounts for almost half of the world's natural gas exports, and Europe with nearly 15\% of the world's consumption of natural gas) provides numerous opportunities, including the pursuit of a stronger energy policy towards the Middle East and the Balkans. ${ }^{14}$

Although Turkey could not be comparable with the EU or Russia in terms of power, its geographical position and historical and cultural factors that make it very close to the Balkans and its foreign policy aims as well,

\footnotetext{
${ }^{14}$ Unlike self-sufficient electricity demand, Turkey is ranked 17th in the world for crude oil imports and 6th in the world for natural gas imports (The World Factbook, 2019; British Petroleum, 2019, p. 35).
} 
make Turkey a very important factor for the Western Balkans' energy security. Some latest trends in terms of Turkey as a growing regional power show that it has a strong interest in investing in the Western Balkans countries (Lachert and Kamiński, 2019). Besides, the statements that Turkey's good geographic location could be used not only for enhancing its power but as a factor to 'boost its prospects for accession to the European Union' are not rare (Winrow, 2013, p. 145).

A comprehensive study on a Balkan gas hub, made by Aleksandar Kovacevic, showed the potential of the region when it comes to gas supply mechanisms and options (2017). The author summarized Turkey's role in this dynamic, showing that the Turkey gas corridor provides at least two supply options for the Balkans:

- The bi-directional flow between Turkey and Bulgaria,

- The TANAP - TAP pipeline system for delivering Caspian (Azerbaijan) gas to the Western Balkans and Italy. The TAP is further accompanied by the Adriatic-Ionian pipeline intended to link the TAP in Albania with the existing (and developing) pipeline system in Croatia (Kovacevic, 2017, p. 31).

Due to the implementation of major energy projects, Turkey has shifted from being a significant transit country to a regional energy hub. ${ }^{15}$ Turkey's energy map is prevailed by two natural gas corridors, the eastern (Iraq, Iran and Qatar) and the northern (Russia, Azerbaijan and other Caspian countries) and several competing energy projects. However, the indicated geopolitical position also creates a series of tensions in Turkey's relations with energy-exporting countries. Intense confrontation between the Nabucco project (supported by the US and the EU) and Blue Stream (supported by the Russian Federation) replaced the competition between the Trans-Adriatic Pipeline (TAP) and the Trans-Anatolian Pipeline (TANAP) versus former South Stream and current Turk Stream project. ${ }^{16}$

\footnotetext{
${ }^{15}$ The first pipeline through Turkey - 'West line' - came from the Russian Federation, via Ukraine, Romania and Bulgaria (singed in 1986, built in 1987 and reached a maximum amount of 6 billion $\mathrm{m} 3$ in 1993). The second pipeline stretched along the eastern route, from Iran in the Tabriz-Erzurum-Ankara route (2001). Shortly after (2003), a Russian project Blue Stream was put into operation, and after that, a gas pipeline from Azerbaijan Baku-TbilisiErzurum (2007) was built nearby. Also, the Kirkuk-Ceyhan crude oil pipeline is an important segment of regional energy maps. The unrealized projects - the Persian gas pipeline on the Iran-Iraq-Turkey, Qatar and Nabucco pipeline - are worthy of mentioning.

${ }^{16}$ Construction of the Trans-Anatolian Natural Gas Pipeline (TANAP, 10 billion m3) began in June 2018, while the first gas deliveries to Europe are expected in early 2020.
} 
Having in mind the previously mentioned, it is obvious that the only viable way to boost European and the Western Balkans' energy security in terms of natural gas is one that includes the pipeline(s) that passes through the Turkish territory.

\section{The Southern Gas Corridor and the Turk Stream projects}

The Southern Gas Corridor. In order to reduce dependence on Russian gas, the European Commission supported the Southern Gas Corridor Initiative (in 2008), which connects to the existing South Caucasus Pipeline, after which two new pipelines are planned: the Trans-Anatolian pipeline (TANAP) (started in 2018) and the Trans-Adriatic pipeline (TAP), whose total value is estimated at around $\$ 40$ billion. ${ }^{17}$ As a project aimed at supplying the EU with Caspian gas via Turkey and with the support of the USA, it has raised many controversial debates wide across Russia.

The Trans-Anatolian pipeline extension and a certain competitor to the Turk Stream appears on the Balkans energy map as a transit project - the Trans Adriatic Pipeline ( 878 km, 90\% completed, expected in 2020, 10 billion cubic meters) - through which it is planned to take Azerbaijani natural gas via Turkey and Greece to the market of Western Europe.

Similar to the case of Turk Stream, Turkey takes a central role within the Southern Gas Corridor, contributing to the strengthening of its overall geopolitical power in the Balkans, especially in relation to Greece. Also, some announcements of the expansion of the Trans-Adriatic pipeline to the Western Balkans countries have further strengthened Turkey's significant energy role in the region.

Although the Southern Gas Corridor currently bypasses states of the Western Balkans, some recent announcements were made regarding its possible extension. In 2018, a series of agreements were signed, providing the construction of the Ionian - Adriatic Pipeline aimed at connecting the energy markets of Albania, Montenegro and Croatia with the Southern Gas Corridor. ${ }^{18}$ This gas project is of obvious significance to the WB countries.

${ }^{17}$ The European Investment Bank approved one of the biggest loans ever, worth 1.5 billion euros, for the Trans-Adriatic Pipeline (De Carbonnel, 2018).

${ }^{18}$ The financial problems of Albania and Montenegro have threatened the realization of the Ionian-Adriatic pipeline. On the other side, during the past year, Croatia has intensified the work on the construction of the LNG terminal in Krk and the connection of the energy network with the surrounding countries, which is an introduction to the construction of the Ionian-Adriatic pipeline (Ibrahimzade, 2019). 
The Turk Stream. The Turk Stream must be seen as a segment of a complex and dynamic global energy competition. Unlike most of the projects supported by the US and the EU so far, the South Stream (2010) was the first to give greater importance to the Western Balkans. The choice of the route testifies to the geopolitical direction of this course, which extends through Bulgaria and Serbia to Central Europe, not as it was once mentioned, via Greece to Italy. However, after the suspension of the South Stream project (in 2014), a memorandum of understanding was signed between Gazprom and BOTAS, whose plans were threatened by the blockade of Russo-Turkish relations (in 2015). However, construction of the new Turk Stream pipeline, worth 11.4 billion euros with a flow of 31.5 billion $\mathrm{m} 3$, is foreseen by a new intergovernmental agreement signed in 2016.

The pipeline project Turk Stream is often presented as 'another giant project after the TANAP' that will together play a key role in ensuring European energy security (Turkey, 2019) and the Western Balkans likewise. ${ }^{19}$ The first part of this pipeline is aimed at supplying Turkey, and the second part goes farther from Bulgaria to Serbia and Hungary, each with $15.75 \mathrm{bcm}$ annual capacity (Tsolova, 2019) and bypassing Ukraine. Separately, Serbia and Hungary are building another pipeline that will carry the gas from the Turk Stream and take it further to the EU. Turkish energy minister designated Turkey as someone who plays a 'key role in securing Europe's gas supply' (Turkey, 2019). Therefore, the TANAP-TAP system and the Turk Stream project are seen as core gas projects for Europe and the Western Balkans' energy security in the future.

On the first day of 2020, Bulgaria started receiving Russian gas via the Turk Stream (Bugarska, 2020). The inauguration event was held on 8 January with Russian, Turkish, and Serbian presidents and Bulgarian prime minister, where the possibility to include North Macedonia, Bosnia and Herzegovina, and Montenegro in the project were also highlighted (TurkStream, 2020). This event was followed by some controversial debates such as the increasing influence of Russia and Turkey in the Balkans (Bojić, 2020) and the division of European countries on 'winners' and 'losers' (Bauomy, 2020), expressing great attention to further developments within European energy security.

${ }^{19}$ Currently, this project (as well as Nord Stream 2) is facing USA economic sanctions. 


\section{CONCLUSION}

In the process of the global energy transformation and overall energy paradigm that expresses the necessity of diversifying energy resources, transport routes and energy partners, some regions are gaining in importance. One of the best examples is the region of the Western Balkans, sitting in a triangle between traditional energy actors in the form of the EU and Russia and Turkey as an emerging 'energy hub'. With key pipelines passing through its territory, Turkey could really become the new 'energy hub' not only for Europe but for the Western Balkans respectively, with seriously improved geopolitical importance and threatening to shake prevailing presumption of RSCT theory in terms of an insulator state.

In accordance with their traditional roles and energy interests and policies within this part of the European continent, the EU and Russia will continue to aspire towards the Western Balkans in the energy security domain, but the role of Turkey must not be neglected so far. Hereof all attention will be pointed to Turkey-EU and Turkey-Russia relations, i.e., energy competition between the EU and Russia. In this atmosphere, the Western Balkans, as energy-hungry countries, could benefit from confronting the main challenges and use given opportunities to improve their own energy security and strengthen their own positions in the overall energy security dynamics.

In addition to the undoubted advantages, from the perspective of the Western Balkans states facing complex political circumstances and economic transformation, the Turk Stream has already posed a number of major political challenges. Turkey's and Russia's global and regional cooperation, especially in the energy security domain, requires an analytical observation of future steps and moves and a pragmatic review of the traditional and dominant enmity-amity patterns characteristic for understanding the role of these countries in the Balkans. In this manner, a lot of future dynamics would also depend on good regional cooperation.

Both natural gas projects confirm Turkey's geostrategic position as an energy hub onto the Western Balkans and the rest of Europe. Strengthening the energy role of Russia and Turkey in the Balkans and Southeast Europe will threaten Western energy positions in this region. Firstly, the realization of the Turk Stream and the North Stream 2 will lead to a decrease in Ukraine's geopolitical importance in the gas transit route to Europe. On the other hand, in addition to Russia and Turkey, Bulgaria and Serbia will undoubtedly benefit from participation within this project. Secondly, the 
completion of the pipeline and the agreed construction of a nuclear power plant in Turkey will strengthen political relations between Turkey and Russia. Thirdly, the construction of the Turk Stream will cause not only a strengthening of the energy presence of Russia and Turkey but also a much greater degree of the energy dependence of the Balkans states. Fourthly, transit countries will realize a number of economic benefits from this cooperation, including smaller transit prices. Finally, it should expect that these factors will strengthen not only the economic but also the overall political influence of Russia and Turkey in the Western Balkans.

\section{REFERENCES}

Barrinha, A. (2014). The ambitious insulator: revisiting Turkey's position in Regional Security Complex Theory. Mediterranean Politics, 19(2), pp. 165182.

Bauomy, J. (2020, January 8). TurkStream: Europe needs gas and Russia has it - the story behind that new pipeline, retrived from https:/ / www.euro news.com/2020/01/08/turkstream-europe-needs-gas-and-russia-hasit-the-story-behind-that-new-pipeline. Accessed 9 January 2020.

Bojić, S. (2020, January 9). Rusija i Turska kontrolišu energetsku budućnost Balkana [Russia and Turkey are controlling the Balkans' energy future], retrieved from https:// www.dw.com/sr/rusija-i-turska-kontroli\% $\mathrm{C} 5 \%$ A1u-energetsku-budu\%C4\%87nost-balkana/a-51939031. Accessed 9 January 2020.

British Petroleum. (2019). BP Statistical Review of World Energy. British Petroleum, London, UK.

Bugarska počela da prima ruski gas preko Turskog toka [Bulgaria started to gain Russian gas via Turk Stream]. (2020, January 1), retrieved from http://www.politika.rs/sr/clanak/445111/Bugarska-pocela-da-primaruski-gas-preko-Turskog-toka. Accessed 4 January 2020.

Buzan, B. \& Waever, O. (2003). Regions and powers: the structure of international security. Cambridge, Cambridge University Press.

De Carbonnel, A. (2018, February 6). UPDATE 1-EIB approves 1.5 bln euro loan for TAP gas pipeline, retrieved from https://de.reuters.com/ article/eu-energy/update-1-eib-approves-1-5-bln-euro-loan-for-tap-gaspipeline-idUKL8N1PW6EY. Accessed 4 January 2020. 
European Council. (2003). The Thessaloniki Agenda for the Western Balkans - Moving Towards European Integration No. C/03/163. European Council, Thessaloniki.

Gazprom Export. (2019). Gazprom Export. St. Petersburg, Russian Federation. GIS Dossier: How Turkey scored big in the gas pipeline game. (2018, October 31), retrieved from https://www.gisreportsonline.com/gis-dossierhow-turkey-scored-big-in-the-gas-pipeline-game,energy,2706.html. Accessed 4 January 2020.

Ibrahimzade, M. (2019, March 15). Croatia intensifying its efforts to realize Ionian-Adriatic Pipeline, retrieved from https://www.azernews.az/ oil_and_gas/147321.html. Accessed 4 January 2020.

Index Mundi. (2019). Thematic Map > Natural gas - consumption - World, retrieved from https://www.indexmundi.com/ map/?v=137. Accessed 4 January 2020.

Kovacevic, A. (2017). Towards a Balkan gas hub: the interplay between pipeline gas, LNG and renewable energy in South East Europe. Retrieved from https://ora.ox.ac.uk/objects/uuid:00ac940a-a4da-4d0a-8bef-be09437 a167c/download_file?file_format=pdf\&safe_filename=Towards-aBalkan-gas-hub-NG-115.pdf\&type_of_work=Working+paper.

Kudlenko, A. (2018). The impact of the EU on security sector reform in the Western Balkans. Kent, Canterbury Christ Church University.

Lachert, J. \& Kamiński, K. (2019, May 29). Conference Report - Western Balkans: Infrastructure, Energy, Geopolitics, retrieved from https:// warsawinstitute.org/western-balkans-infrastructure-energygeopolitical-perspective/. Accessed 29 October 2019.

Lipovac, M. V. (2016). Nacionalna bezbednost Republike Srbije u regionalnom bezbednosnom potkompleksu Zapadni Balkan [The Republic of Serbia National Security in the Western Balkans Regional Security Complex]. Belgrade, Faculty of Security Studies.

Luenam, J. (2015). Rethinking Turkey's position in the Middle eastern regional security complex: from insulator to regional leader?. Cairo, The American University in Cairo.

Nedučin, A. (2018, July). Zapadni Balkan i prirodni gas - želje i realnost. Bilten Nacionalnog naftnog komiteta Srbije - Svetskog naftnog saveta, 28, retrieved from https://www.wpcserbia.rs/wp-content/uploads/2018/ 07/18-10-FINAL.pdf. Accessed 29 October 2019.

Önsoy, M., \& Udum, S.. (2015). The role of Turkey in western Balkans energy security. Asia Europe Journal, 13(2), pp. 175-192. 
Ralchev, S. (2012). Energy in the western Balkans: a strategic overview. Sofia, Institute for Regional and International Studies.

The World Factbook. (2019, November 22), retrieved from https:/ / www.cia. gov/library/publications/the-world-factbook/geos/tu.html. Accessed 21 December 2019.

Tichý, L. (2019). EU-Russia Energy Relations: A Discursive Approach. Cham, Springer International Publishing.

Trapara, V. \& Šekarić, N. (2019). Saradnja kao (ne)očekivani efekat energetske bezbednosne dileme: studija slučaja Bugarske, Grčke i Jugoslavije [Cooperation as an (Un)Expected Effect of Energy Security Dilemma: The Case of Bulgaria, Greece and Yugoslavia]. Medunarodni problemi, 71(2), pp. 215-243.

Tsolova, T. (2019, December 30). Bulgaria to get Russian gas supplies via TurkStream, retrieved from https://www.reuters.com/article/usbulgaria-russia-gas/bulgaria-to-get-russian-gas-supplies-viaturkstream-idUSKBN1YY0SW. Accessed 4 January 2020.

Turkey to launch TurkStream on January 8. (2019, December 28), retrieved from http://www.hurriyetdailynews.com/turkey-to-launch-turkstream -on-january-8-150366. Accessed 29 December 2019.

TurkStream is a matter of 'national \& energy security' for Turkey \& EU... and US can't derail it now. (2020, January 9), retrieved from https:// www.rt.com/business/477772-turkstream-national-energy-securitymatter/. Accessed 9 January 2020.

UN. (2016). Energy Statistics Yearbook. https://unstats.un.org/unsd/ energystats/pubs/yearbook/2016/t27.pdf. Accessed 10 January 2020.

Veličkovski Stojanovski, I. M. (2019). Uticaj Evropske unije na transformaciju regionalnog bezbednosnog potkompleksa Zapadni Balkan [The Impact of the EU in the Transformation of the Western Balkans Regional Security Subcomplex]. Belgrade, Faculty of Security Studies.

Winrow, G. M. (2013). The southern gas corridor and Turkey's role as an energy transit state and energy hub. Insight Turkey, 15(1), pp. 145-163.

Yorucu, V., \& Mehmet, O. (2018). The Southern Energy Corridor: Turkey's Role in European Energy Security. Cham, Springer International Publishing.

Zakić, K. \& Radišić, B. (2019). China's Belt and Road Investment Projects in the Balkan Countries: Six Years After. Review of International Affairs, LXX (1175), pp. 49-68. 